EDITORIAL

\title{
BREXIT AFTER THE NEGOTIATION OF THE TRADE AND COOPERATION AGREEMENT: WHO TAKES BACK CONTROL OF WHAT?
}

\author{
El Brexit tras la negociación del acuerdo de comercio \\ y cooperación: íquién recupera el control de qué? \\ PIET EECKHOUT ${ }^{1}$ \\ p.eeckhout@ucl.ac.uk
}

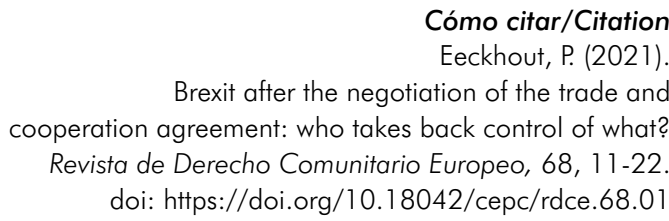

It seems to have finally happened. Nearly five years after the Brexit referendum (June 2016), the United Kingdom has taken back control of its own laws by exiting, on 1 January 2021, the transition period set up by the Withdrawal Agreement. ${ }^{2}$ EU law no longer applies, and nor does the jurisdiction of the European Court of Justice (ECJ). Those are the headlines that Leavers embrace as making good on the Leave campaign's promises. The full force of EU law is gone, and instead comes what is primarily a trade relationship between what the UK Government likes to denote as "sovereign equals". ${ }^{3}$ The Trade and Cooperation Agreement (the TCA) is indeed, in many

\footnotetext{
1 Professor of EU Law, Dean of the UCL Faculty of Laws and Academic Director of the European Institute.

2 Agreement on the withdrawal of the United Kingdom of Great Britain and Northern Ireland from the European Union and from the European Atomic Energy Community (hereafter 'Withdrawal Agreement'), (2019) OJ C 384 I, p. 1.

3 See Frost (2021).
} 
respects, a run-of-the-mill trade agreement, whose commitments are located on the international plane, and whose provisions have no direct effect. ${ }^{4}$ The United Kingdom turns away from the central EU innovation, namely that an international treaty creates directly effective rights and obligations for private parties, which they can enforce under domestic law. ${ }^{5}$ An innovation that lies at the basis of the integrated market the EU has created, and from which the United Kingdom also turns away; but the latter much more grudgingly, it would seem. The move away from internal market membership, which could have been maintained through participation in the European Economic Area, is a price the United Kingdom is willing to pay for throwing off the yoke of EU law. The fact that this is a price, and not a gain, is exemplified by the Global Britain project, which aims to find more trade and business on more distant shores. At least in economic terms the Brexit project was never an overtly protectionist one. It is, at heart, a project of "taking back control", and of "making our own laws" - often even expressed by the much more august notions of sovereignty and independence. Nevertheless, Brexit may also be seen to transcend British idiosyncrasies, and to be part of a bigger trend of popular pushback against the forces of globalisation which are perceived to be assisted by international institutions and organisations.

The completion of this Brexit phase ${ }^{6}$ offers a good opportunity to assess the extent to which Brexit has indeed returned control of its own laws to the United Kingdom. That is what this editorial proposes to do, by looking in a bit more detail at the essential elements of the TCA (and, where relevant, of the Withdrawal Agreement). It is a first assessment, but not an uninformed one. The Brexit process itself provides plenty of context and analysis, and the wider backdrop of the current state of international economic law is not a blank canvas.

The immediate focus of this editorial is on trade and economic relations between the United Kingdom and the European Union, and on the future relationship between UK law and EU law. The assessment is in two parts. I first look at the difficult balancing act, in the TCA, between the Parties' "right to regulate" and the EU's demand of a level playing-field. I then look at the

4 Trade and Cooperation Agreement between the European Union and the European Atomic Energy Community, of the one part, and the United Kingdom of Great Britain and Northern Ireland, of the other part, (2020) OJ L 444, p. 14.

5 Case C-26/62 Van Gend en Loos EU:C:1963:1.

6 Whether this is the final act remains very much to be seen, see Craig $(2016,2017$, 2020 and 2021). 
Brexit version of sovereignty, and expose its limitations - what I call sovereignty's dead ends.

\section{RIGHT TO REGULATE AND LEVEL PLAYING-FIELD: A DIFFICULT BALANCING ACT}

The United Kingdom's conception of Brexit, particularly after PM Johnson took the reins, is one in which there is little or no place for shared laws and regulations, between the EU and the United Kingdom. The goal of removing any role for the ECJ (at least in the TCA) pushed the negotiators to frame the future trade relationship with as little reference as possible to extant or future EU law. In this respect, the United Kingdom's goal was reinforced by the principle of the autonomy of EU law. As is well-known, that principle does not tolerate the incorporation of EU law in an external agreement, or even the close copying of EU law, if the ECJ cannot be given the final say about the interpretation of the relevant EU law provisions. ${ }^{7}$ The result is remarkable, in that the TCA hardly references EU law instruments at all. Its provisions need to be juxtaposed to "internal" EU law, even in areas where the TCA's aim is clearly to be closely aligned with EU law. The provisions on subsidies offer a good example: they are arguably a State aid regime masquerading as a more standard, WTO-like subsidies regime. ${ }^{8}$

Overall, however, the United Kingdom resisted alignment (or convergence), and the result is a shallow trade agreement. To the uninitiated reader the TCA may come across as extensive and complex, but appearances are deceptive. It is really mainly an agreement that removes tariffs in EU-UK trade, and no other trade barriers. It is a WTO-plus agreement, with a small plus. ${ }^{9}$ Perspective is important here. In developed economies like the EU and the UK, tariffs are generally low, and are no longer conceived of as a significant protectionist instrument, with the exception of limited products and sectors (mainly agriculture). That has been the case for several decades now. The main barriers to trade are of a regulatory kind, which is something which every EU internal market lawyer instantly recognises. The EU has responded to this basic feature of contemporary globalisation by creating an entire eco-system of rules and institutions that aim to overcome those regulatory barriers. In a nutshell, and conscious of the risks inherent in re-stating the canon, some

\footnotetext{
See e.g. Eckes (2020).

See Peretz (2021).

See for a general analysis Horn, Mavroidis, and Sapir (2010).
} 
of the core elements of that system are the following. First, ECJ case law which accepts that mere regulatory divergence - the fact that Member States have different regulations on e.g. the minimum alcohol content of alcoholic drinks ${ }^{10}-$ is a barrier to trade. Second, the principle, both in case law and in EU harmonisation legislation, that Member States should mutually recognise the validity of their respective product laws and regulations. Third, a programme of EU harmonisation where that is needed to remove what would otherwise be permitted barriers resulting from regulatory divergence. Fourth, the institutional dimension of "agencification", in the sense of the creation of specialised regulatory agencies at EU level. ${ }^{11}$ As I have stated and analysed elsewhere, this could be called the EU's market integration paradigm; ${ }^{12}$ a paradigm that is also employed in federal States, but not much at all in other international organisations, or bilateral or multilateral trade agreements. The market integration paradigm can be contrasted with the trade liberalisation paradigm. The latter aims to reduce barriers to trade at the border, but keeps distinct and differently regulated markets wholly intact.

As the United Kingdom sought to throw off the yoke of EU law, it proved impossible to tackle regulatory divergence in anything but the most minimal ways. Nowhere is this clearer than in the area of trade in services, with financial services as the best example. Intra-EU free trade in financial services, denoted by the term passporting, is dependent on acceptance of the EU financial services rule-book, and of the role of the various European Supervisory Authorities (ESAs). The slogan, perhaps even ideology, of "taking back control" precluded the United Kingdom's continued acceptance of this rule-book, as did the EU's rejection of any picking of the best cherries of the internal market. The result is effectively, as Moloney has demonstrated, a no-deal in financial services (Moloney, 2021).

This minimalist approach to trade liberalisation (which is in reality a return to massive trade barriers) is the result of the United Kingdom's goal to take back control. But we should also recognise that the EU, too, seeks to retain control. The concept here is the "right to regulate", a concept which can be found throughout the TCA. ${ }^{13}$ In EU law, it has its pedigree in Opinion $1 / 17$, on the CETA agreement with Canada, where the ECJ elevated the EU's right to regulate to a constitutional principle that is part of the autonomy

10 Case C-120/78 Rewe-Zentral AGv Bundesmonopolverwaltung für Branntwein (Cassis de Dijon) EU:C:1979:42.

11 See Chamon (2016).

12 See Eeckhout (2018).

13 See Arts. SERVIN.1.1(2); DIGIT.3; ENER.5(4); LPFS.1.2. 
of EU law. ${ }^{14}$ This right to regulate means that the EU should be free to "determine the level of protection" in a wide range of public policy areas, such as public health, environmental and social policies.

The EU's conception of its own right to regulate was hard to reconcile with its initial demands for dynamic alignment or convergence, as expressed in the Political Declaration attached to the Withdrawal Agreement. ${ }^{15}$ Such dynamic alignment was always seen to be one-directional: for the UK to align with any future, and higher, levels of protection in the EU. The subtext was very much the fear of a Singapore-on-Thames: the idea that the United Kingdom would substantially deregulate its economy after Brexit, and would definitely not want to be in tow with more stringent EU regulatory systems. However, the TCA could hardly confirm a right to regulate on behalf of the EU, but not of the United Kingdom. This must form part of the reasons why dynamic alignment had to be abandoned.

In fact, the TCA eschews the terms "convergence", "divergence" and "alignment". But it does have a whole title devoted to "level playing field for open and fair competition and sustainable development". Most of the provisions of that title are indeed aimed at ensuring continued alignment of a range of public policies - competition policy (including subsidies), taxation, labour and social standards, environment and climate - and to managing divergence. It must again be noted that this TCA title does not reference, let alone include extant or future EU legal instruments. But that does not mean the provisions are weak or narrowly focused. Nor does it mean that the United Kingdom is able to escape from the constraints of extant EU law. It may be useful to give some examples and to unpack this a little more.

Take the provisions on non-regression in environmental and climate matters. Art 7(2) provides that "a Party shall not weaken or reduce, in a manner affecting trade and investment between the Parties, its environmental levels of protection or its climate level of protection below the levels that are in place at the end of the transition period, including by failing to effectively enforce its environmental law or climate level of protection". Those "levels that are in place", in the United Kingdom, are of course mostly determined by EU law. True, the non-regression obligation is limited to cases of lowering which affect trade and investment between the United Kingdom and the EU. But "affecting" is a generous term, and it will not be difficult to show an effect on trade and investment of any significant lowering of standards. That means that in particular the United Kingdom's right to

14 Opinion 1/17 re CETA EU:C:2019:341.

15 (2019) OJ C 384 I, p.178. 
regulate is strictly qualified: free to maintain current levels of protection, or to increase them; not free to lower them. I say "in particular the United Kingdom", because the EU is in any event characterised as a kind of upward regulator. As McCrea has shown, the EU cannot really stand still (McCrea, 2017), and it is difficult to imagine it lowering levels of protection in key policy areas, such as the environment, other than through disintegration.

This kind of non-regression clause is also found in the area of labour and social standards. ${ }^{16}$ This means that in the important policy fields of environmental protection and labour standards the United Kingdom's right to regulate is by no means a complete one. Any significant attempts at deregulation would be caught by the TCA.

Art 7.4.1 offers a further example of the stringent demands in the area of environmental protection. It binds the parties to a number of internationally recognised environmental principles, such as the precautionary principle and the polluter-pays principle. Those principles are of course the cornerstones of the EU's environmental policy, and are set out in the TFEU. ${ }^{17}$ Art 7.4.1 does not refer to the TFEU, but references international instruments such as the Rio Declaration on Environment and Development, and the UN Framework Convention on Climate Change. The alignment with core EU law principles is nevertheless striking, and also restricts the United Kingdom's right to regulate.

A last example is that, even if the TCA does not reference EU law, it extensively references international instruments in the sphere of trade and sustainable development. Chapter 8 of the level playing field title is devoted to enhancing "the integration of sustainable development, notably its labour and environmental dimensions, in the Parties' trade and investment relationship and in this respect to complement the commitments of the Parties under Chapter 6 [Labour and social standards] and Chapter 7 [Environment and climate]". ${ }^{18}$ The provisions that follow refer to a whole series of instruments, such as the core labour standards embodied in ILO Conventions; ${ }^{19}$ the ILO Decent Work Agenda; ${ }^{20}$ a series of multilateral environmental agreements; ${ }^{21}$ the Convention on Biological Diversity

16 See Art. LPFS.6.2.

17 See Art. 191(2) TFEU. See, further, Scotford (2017).

18 See Art. LPFS.8.1.

19 Art. LPFS 8.3.2.

20 Art. LPFS 8.3.6.

21 Art. LPFS 8.4. 
and CITES; ${ }^{22}$ and FAO and UNCLOS instruments. ${ }^{23}$ At first glance, these are all agreements to which the EU and the United Kingdom are already parties, and the TCA Parties are not required to join any new or existing agreements. It is nevertheless the case that the referencing and incorporation of these instruments in the TCA also commits the United Kingdom to continued respect for the basic principles which those instruments express. Again, that is a significant restriction on its right to regulate. And it is noteworthy that the United Kingdom accepts one set of international commitments (non-EU ones) but rejects virtually all references to EU law.

It is of course one thing to bind the United Kingdom to a whole series of principles and provisions in a wide range of public policies; the enforcement of those commitments is a different matter. It is not the purpose of this editorial to engage in any depth with the TCA provisions on dispute settlement, and on enforcement and sanctions. It is a complex set of provisions, no doubt at least in part the result of a lack of trust between the Parties in the course of the negotiations. Art 9.4 on rebalancing is particularly noteworthy. Ultimately, though, the scope for effective sanctions which are capable of inducing a change in conduct is limited by the shallowness of the free trade which the TCA establishes. In the main, a reintroduction of tariffs is what the Parties have in their armour. Nevertheless, even if actual enforcement may be precarious, the commitments do have the force of international law and are extensive. They continue to bind the United Kingdom to important EU policies, on competition, taxation, environmental protection, and social and labour standards, and preclude it from using subsidies in not too dissimilar ways from the disciplines that EU State aid law imposes on the Member States (Peretz, 2021).

On the basis of this initial assessment we may conclude that, as part of a shallow, WTO plus trade agreement, the United Kingdom has accepted extensive commitments on level playing field, which bind it to at least non-regression in significant policy areas. Its right to regulate is formally recognised, but needs to be exercised by either going more slowly or more quickly than the EU in the level playing field areas. It cannot be exercised by way of a wholesale deregulatory exercise or of a fundamental reconsideration of government policies that affect trade and investment. Taking back control is a relative concept.

22 Art. LPFS 8.6.

23 Art. LPFS 8.8. 


\section{BREXIT SOVEREIGNTY AND ITS DEAD ENDS}

If the provisions of the TCA on level playing field limit the extent to which Brexit allows the United Kingdom to take back control, there are further ways in which the Brexit version of sovereignty remains a relative concept. It is not the purpose of this editorial to conceptualise Brexit sovereignty, ${ }^{24}$ let alone sovereignty generally. What I mean here by Brexit sovereignty is the United Kingdom's ability to take back control, i.e. to be no longer bound by EU law, in both a formal and practical sense. And the argument I want to develop is that this project risks meeting its inherent as well as contingent limits in what could be called a number of dead ends.

The first of those is the set of TCA provisions on level playing field, referred to above. Whilst they do not formally reference EU law, they are nonetheless a close reflection of significant EU policies and values. Moreover, the shallow nature of the trade agreement will undoubtedly lead to further pressure for a return to a closer relationship; one that gives better access to the EU internal market. Yet in this respect, Brexit sovereignty leads the United Kingdom up a dead end. A closer relationship requires the acceptance of at least certain parts of EU law, as is exemplified by all the agreements the EU has with its other neighbours and which give internal market access. ${ }^{25}$ That in turn requires an acceptance of the role of the ECJ as the final interpreter of EU law. As long as Brexit sovereignty eschews both dimensions of a closer relationship, it will not be possible for the United Kingdom to obtain better market access.

The so-called Brussels Effect constitutes the second dead end. As the extensive analysis by Bradford (2020, and also by Scott) ${ }^{26}$ has shown, EU law spreads its wings beyond Europe because of the size of the EU market and the drive and ambition that characterise the $\mathrm{EU}$ as a regulator. Often EU standards effectively become world standards, because they are embraced by companies aiming to serve world markets. REACH (chemicals) and GDPR are two obvious examples.

There can be little doubt that the Brussels Effect will extend to UK manufacturers (and service providers) seeking to export to the EU. It is interesting to hold the TCA up against the Brussels Effect light. As analysed above, the TCA eschews EU law, particularly as regards specific product and market

24 On this, see (Elliott, 2020).

25 This is the case for the EEA; the agreements with Switzerland; and the association agreement with Ukraine; see Eeckhout (2018).

26 See e.g. Scott (2020:16) and Cremona and Scott (2019). 
regulations. If, however, UK companies continue to produce in accordance with EU standards, the Brussels Effect will ensure that those companies continue to apply EU law, and do not gain a competitive advantage through the use of different standards. What those companies lose, though, is the automatic market access which comes with trading inside the EU internal market (including the EEA). The recent upheaval about exports of shellfish products exemplifies all this. ${ }^{27}$

Bradford in her analysis distinguishes between de facto and de iure Brussels Effects. The latter occurs when non-EU governments also formally adopt an EU regime, simply because it reflects what companies are asking for so as to trade well with the EU. She notes that, in the context of Brexit, there is already a de iure Brexit effect as regards e.g. GDPR (Bradford, 2020: 279-280). It is indeed the case that the United Kingdom has fully adopted GDPR, and that the Government shows no signs of seeking to abandon it. In fact, at the start of post-transition Brexit, this de iure Brussels Effect extends to most EU laws, as the UK withdrawal legislation has kept them on the statute book. This means that, in contrast with other third countries, no active passing of laws which in substance copy EU law is required. The question is rather whether the United Kingdom will seek to diverge, for example in an area like financial services. The cost of divergent UK and EU regimes to UK companies seeking to serve the EU's market will be a constant factor, working against divergence.

There is a close relationship here with so-called equivalence regimes which the EU employs. In a number of areas that are not subject to multilateral rules (such as those of the WTO), the EU's internal market regulation requires third countries to show the equivalence of their regimes in order to gain access. GDPR (where the term "adequacy" is used rather than equivalence) and financial services are prominent examples. In all of those areas, there will be a significant cost to full Brexit sovereignty. The lack of equivalence will amount to a loss of market access, and equivalence means that EU law continues to cast its long shadow.

The third dead end consists of the formal effect of EU law, in the United Kingdom. Under the current agreements, the United Kingdom is by no means completely successful in its attempts to throw off the yoke of EU law. There is, first of all, the Withdrawal Agreement, whose provisions have direct effect, in much the same way as EU law did in the course of the United Kingdom's membership. ${ }^{28}$ The most significant parts of that Agreement, for direct effect purposes, are those on citizens' rights, as well as the Protocol on

27 See "EU sinks UK hopes of overturning shellfish ban", Financial Times, 11 Feb 2021. 28

See Art. 4 WA. 
Ireland/Northern Ireland. The former are destined to become extinct, and their effect is a function of the longevity of those EU citizens who benefit from the acquired rights which the Agreement protects. The provisions of the Protocol, however, are intended to endure. They are a "frontstop", following the United Kingdom's rejection of a backstop Protocol. Their effect is not confined to Northern Ireland territory. The provisions on customs, trade checks, and indeed State aid may have to be applied in Great Britain too. This is not a minimal set of provisions.

The TCA, on the other hand, emphatically excludes direct effect. It states in Art COMPROV.16(1) that nothing in the Agreement "shall be construed as conferring rights or imposing obligations on persons other than those created between the Parties under public international law, nor as permitting this Agreement or any supplementing agreement to be directly invoked in the domestic legal systems of the Parties". At first glance, this looks conclusive as to any effect of the TCA in UK domestic law. However, there are essentially two routes through which an international agreement can produce direct effect. The agreement itself may provide for such effect, but that is a rare occurrence; even the TEU and the TFEU do not expressly speak to their domestic legal effect. ${ }^{29}$ The other route is through the domestic law of a contracting party, which may either be case law or legislation.

Given the Brexit project of taking back control, one would not expect the United Kingdom to use this second route. It is therefore remarkable to see that the EUFRA appears to be doing just that. In Section 29(1) it speaks to the implementation of the TCA, in the following terms:

Existing domestic law has effect on and after the relevant day with such modifications as are required for the purposes of implementing in that law the Trade and Cooperation Agreement or the Security of Classified Information Agreement so far as the agreement concerned is not otherwise so implemented and so far as such implementation is necessary for the purposes of complying with the international obligations of the United Kingdom under the agreement.

The interpretation of this provision is not straightforward..$^{30}$ However, it does lend itself to a reading which would allow the UK courts to give effect to the TCA, even when that means overriding any "existing domestic law". The term "implementing" (the TCA) is not defined. Section 31 confers the power of implementation on any "relevant national authority", and states that it can

29 With the exception of Art. 288 TFEU, which defines regulations as being directly applicable in all Member States.

30 See further Craig (2021). 
be exercised by way of regulations. That is a clear reference to the executive. But Section 31 does not expressly limit TCA implementing power to the executive, and it will surely be argued, before the courts, that they too should only apply existing domestic law to the extent that it requires no modification for the purpose of implementing the TCA. Where a court is capable of applying the TCA provisions directly, because there is no discretion involved, Section 29(1) appears to oblige it to do so. If the concept behind the EUFRA provisions on implementation had been that only the UK Government is given authority to implement the TCA, the EUFRA provisions would have been framed differently: as giving the Government exclusive implementing power, including the power to modify existing domestic law. However, Section 29(1) speaks to the continued effect of existing domestic law, not just to a power of implementation.

The TCA may therefore acquire some form of direct effect, through the operation of Section 29(1) EUFRA. Of course, the TCA is not to be equated with EU law. As analysed above, it contains hardly any direct references to EU law. But parts of it, e.g. on subsidies, do seem a close fit with the corresponding EU law system. Here, too, then, is a dead end for the Brexit sovereignty project.

\section{CONCLUSION}

This initial analysis of the TCA shows that the slogan of "taking back control" is difficult to implement, even by a government that is keen on doing so, to the point of being ideological about it. ${ }^{31}$ The EU's insistence on a level playing field, the need to avoid a border between Ireland and Northern Ireland, the Brussels Effect, the direct effect of the Withdrawal Agreement, and the UK implementation of the TCA are all elements, which severely limit Brexit sovereignty. The analysis of those limitations also exposes the fundamental flaws of this project. At the heart of those flaws sits an unresolved and unresolvable tension between taking back control and continuing to benefit from free trade and movement. That tension prevents the United Kingdom from reclaiming an absolutist form of sovereignty. It is moreover difficult to see how even the current form of Brexit sovereignty will withstand the test of time, in a globalised world. What really is the gain of throwing off the yoke of EU law?

31 See "Inside the Brexit deal: the agreement and the aftermath", Financial Times Magazine, 22 January 2021. 


\section{Bibliography}

Bradford, A. (2020). The Brussels Effect - How the European Union Rules the World. Oxford: Oxford University Press. Available at: https://doi.org/10.1093/ oso/9780190088583.001.0001.

Chamon, M. (2016). EU Agencies - Legal and Political Limits to the Transformation of the EU Administration. Oxford: Oxford University Press. Available at: https:// doi.org/10.1093/acprof:oso/9780198784487.001.0001.

Craig, P. (2016). Brexit: A Drama in Six Acts. European Law Review, 41(4), 447-448.

Craig, P. (2017). Brexit, A Drama: The Interregnum. Yearbook of European Law, 36-45.

Craig, P. (2020). Brexit, A Drama: The Endgame - Part I. European Law Review, $16-182$.

Craig, P. (2021). Brexit a Drama: The Endgame - Part II: Trade, Sovereigny and Control. European Law Review, forthcoming.

Cremona, M. and Scott, J. (eds). (2019). EU Law Beyond EU Borders: The Extraterritorial Reach of EU Law. Oxford: Oxford University Press. Available at: https:// doi.org/10.1093/oso/9780198842170.001.0001.

Eckes, C. (2020). The autonomy of the EU legal order. Europe and the World Law Review (4)1, 1. Available at: https://doi.org/10.14324/111.444.ewlj.2019.19.

Eeckhout, P. (2018). Future Trade Relations between the EU and the UK: Options after Brexit. Available at: https://bit.ly/3ePNq4C.

Elliott, M. (2020). The UK-EU Brexit Agreements and 'sovereignty': Having one's cake and eating it? Public Law for Everyone, [blog]. Available at: https://bit. ly/3qQwv4h.

Frost, D. (2021). Brussels needs to shake off its remaining ill-will and treat Brexit Britain as an equal. The Telegraph.

Horn, H.; Mavroidis, P. and Sapir, A. (2010). Beyond the WTO? An anatomy of EU and US preferential trade agreements. The World Economy, 33(11), 1565-1588. Available at: https://doi.org/10.1111/j.1467-9701.2010.01273.x.

McCrea, R. (2017). Forward or Back: The Future of European Integration and the Impossibility of the Status Quo. European Law Journal, 23(1-2), 66-93. Available at: https://doi.org/10.1111/eulj.12207.

Moloney, N. (2021). Financial Services under the Trade and Cooperation Agreement: Reflections on Unfinished Business for the EU and the UK. Brexit Institute Working Paper 3. Available at: https://bit.ly/3tywp31.

Peretz, G. (2021). The subsidy control provisions of the UK-EU trade and cooperation agreement: a framework for a new UK domestic subsidy regime. $E U$ Relations Law [blog], 28-12-2020. Available at: https://bit.ly/3bWNYns.

Scotford, E. (2017). Environmental Principles and the Evolution of Environmental Law. Oxford: Hart Publishing.

Scott, J. (2020). The Global Reach of EU Law. In A. Reich and H.-W. Micklitz (eds). The Impact of the European Court of Justice on Neighbouring Countries (pp. 21-63). Oxford: Oxford University Press. 